\title{
Peningkatan Kemampuan Berbahasa Inggris Bagi Siswa SMP
}

\author{
Julanos $^{1 *}$, Nur Budi Nugraha ${ }^{2}$, Jhon Suarlin ${ }^{3}$ \\ ${ }^{1,3}$ Program Studi Teknik Industri, Sekolah Tinggi Teknologi Dumai, Indonesia \\ ${ }^{2}$ Program Studi Teknik Informatika, Sekolah Tinggi Teknologi Dumai, Indonesia \\ Email: 1julanos279@gmail.ac.id, 2nurbudinugroho87@gmail.ac.id, ${ }^{3}$ jhonsuarlin@ gmail.ac.id
}

\section{INFORMASI ARTIKEL}

\section{Data artikel:}

Naskah masuk, 4 Mei 2020

Direvisi, 20 Juli 2020

Diiterima, 21 Agustus 2020

\section{Kata Kunci:}

Simple Present Tense

ICT

Video Animasi

\begin{abstract}
ABSTRAK
Abstract- One of the main objectives of studying English is to increase ability in English conversation. However, English conversation skills are still considered as one of the skills that are difficult for students to do. Many students face some difficulties when they want to communicate in English, even though they have studied English for years. Some of the difficulties students often face and complain about are the first, they are not able to communicate in English, because they do not master English vocabulary. Secondly, they are afraid and lacking confidence in the ability to speak English vocabulary and thirdly, there is no attractive media and learning methods to involve students communicating in English. Therefore, effective and efficient solutions are needed to increase students' interest in understanding English subjects by providing interesting teaching media, and effective learning methods. One of the interesting teaching media is the use of ICT (Information and Communication Technology) into it, one of which is video animation. Effective and efficient media and methods can help students engage in learning English and at the same time be motivated to communicate in English. The target of the implementation of this community service activity is Class 7 students of Bazma Brilliant Middle School. This activity provides knowledge about the media and methods of learning English conversation in the form of tips and strategies to increase students' interest in learning and communicating in English.
\end{abstract}

Abstrak- Salah satu tujuan utama mempelajari bahasa Inggris adalah untuk meningkatkan kemampuan dalam percakapan bahasa Inggris. Namun, kemampuan percakapan bahasa Inggris masih dianggap sebagai salah satu keterampilan yang sulit dilakukan bagi siswa. Banyak siswa menghadapi beberapa kesulitan ketika mereka hendak berkomunikasi dengan bahasa Inggris, walaupun mereka sudah belajar bahasa Inggris selama bertahun-tahun. Beberapa kesulitan yang sering dihadapi dan dikeluhkan siswa diantaranya adalah pertama, mereka tidak mampu berkomunikasi dengan bahasa Inggris, karena mereka tidak menguasai kosa-kata bahasa Inggris. Kedua, mereka takut dan kurang percaya diri terhadap kemampuan untuk mengucapkan kosa kata bahasa Inggris serta ketiga, belum adanya media dan metode pembelajaran yang menarik untuk melibatkan siswa berkomunikasi dengan bahasa Inggris. Oleh karena itu, solusi yang efektif dan efisien diperlukan untuk 


\section{Korespondensi:}

meningkatkan minat siswa dalam memahami mata pelajaran bahasa inggris yaitu dengan menyediakan media pengajaran yang menarik dan metode pembelajaran yang efektif. Salah satu media pengajaran yang menarik adalah dengan penggunaan ICT (Information and Communication Technology) kedalamnya salah satunya adalah video animasi. Media dan metode yang efektif dan efisien dapat membantu siswa terlibat untuk belajar bahasa Inggris dan sekaligus termotivasi untuk berkomunikasi dengan bahasa Inggris. Sasaran dari pelaksanaan kegiatan pengabdian ini adalah para siswa Kelas 7 SMP IT Bazma Brilliant. Kegiatan ini memberikan pengetahuan tentang media dan metode pembelajaran percakapan bahasa Inggris berupa tips dan strategi untuk meningkatkan minat siswa dalam belajar dan berkomunikasi dengan bahasa Inggris.

\section{Julanos}

Program Studi Teknik Industri, Sekolah Tinggi Teknologi Dumai

J1. Utama Karya Bukit Batrem II Dumai, Riau, Indonesia

\section{PENDAHULUAN}

Motivasi menjadi salah satu kebutuhan penting dalam proses pembelajaran (Di, Operasi, \& Pusri, 2016). Pengaruh motivasi terhadap pembelajaran dapat dilihat dari keterlibatan dan respon siswa terhadap materi yang diajarkan. Semakin tinggi keterlibatan dan respon siswa terhadap pembelajaran, semakin baik prestasi belajar yang akan mereka capai. Hal ini juga berlaku dalam pembelajaran bahasa Inggris khususnya percakapan bahasa Inggris (conversation) (Emda, 2018).

Pada kenyataanya, banyak siswa belum termotivasi untuk terlibat dan merespon kegiatan percakapan bahasa Inggris. Hal ini disebabkan kurangnya peranan guru memotivasi siswa dalam kegiatan percakapan bahasa Inggris ini (Santosa, 2018). Misalnya, siswa tidak diberikan media pengajaran yang menarik sekaligus juga tidak diterapkan metode pembelajaran yang tepat dan mendukung sehingga mereka tidak tertarik untuk terlibat mempelajari bahasa Inggris termasuk materi percakapan bahasa Inggris. Padahal, kemampuan dalam percakapan bahasa Inggris merupakan salah satu tujuan utama mempelajari bahasa Inggris dalam menghadapi perkembangan ilmu pengetahuan di era globalisasi sekarang ini(Muhammad, 2017).
Kemampuan percakapan bahasa Inggris dianggap sebagai salah satu keahlian yang sulit dilakukan bagi siswa. Banyak siswa menghadapi beberapa kesulitan ketika mereka hendak berkomunikasi dengan bahasa Inggris. Walaupun mereka sudah belajar bahasa Inggris selama bertahun-tahun. Beberapa kesulitan yang sering dihadapi dan dikeluhkan siswa diantaranya adalah siswa menganggap mereka tidak mampu berkomunikasi dengan bahasa Inggris, karena mereka tidak menguasai kosakata bahasa Inggris sehingga sulit untuk menyampaikan gagasan ataupun ide ketika berkomunikasi dengan bahasa Inggis. Selain itu, mereka juga takut dan kurang percaya diri terhadap kemampuan untuk mengucapkan kosa kata bahasa Inggris. Oleh karena itu siswa membutuhkan pembelajaran yang menarik dalam meningkatkan minat belajar belajar dan berkomunikasi dengan bahasa Inggris (Jelantik Swasta, 2014).

Sebagai solusi untuk memotivasi siswa belajar dan berkomunikasi dengan bahasa Inggris adalah menyediakan media pengajaran yang menarik dan metode (cara) pembelajaran yang efektif. Salah satu media pengajaran yang menarik adalah menggunakan media film (Purnaningsih, 2017) (Purnaningsih, 2017). Film merupakan media berbentuk animasi dan bergambar yang dapat menarik perhatian siswa untuk mempelajari bahasa Inggris. Dalam film 
juga disajikan certita yang menarik dan ditampilkan dengan nuansa imajinatif. Dengan kata lain, media film dapat membantu siswa tertarik untuk belajar bahasa Inggris dan mau terlibat dalam pembelajaran bahasa Inggris (Andy, Rusfandi, \& Muzammil, 2018).

Selain itu, metode pembelajaran yang efektif dan efisien juga dapat membantu siswa memahami informasi yang diberikan. Salah satu metode pembelajaran yang dapat diterapkan untuk memotivasi siswa berkomunikasi dengan bahasa Inggris adalah menggunakan video animasi (Tadulako, 2018). Hal ini dapat membantu siswa memahami kosakata dialog film berbahasa Inggris. Dengan kata lain, media pengajaran dan metode pembelajaran merupakan dua hal penting yang tidak dapat dipisahkan dan saling mendukung sebagai sarana bagi siswa dalam memahami informasi yang diberikan (Ratminingsih, 2016). Media dan metode yang efektif dan efisien dapat membantu siswa terlibat untuk belajar bahasa Inggris dan sekaligus termotivasi untuk berkomunikasi dengan bahasa Inggris (Sulasih, 2017).

\section{METODE PELAKSANAAN}

Metode kegiatan yang dilakukan meliputi sebagai berikut :

1. Persiapan sebelum kegiatan

Sebelum melaksanakan kegiatan ini, diperlukan beberapa yang harus dipersiapkan yag meliputi :

a. Mengumpulkan 1-2 orang mahasiswa untuk membantu kegiatan pengabdian

b. Mengunjungi sekolah SMPIT Bazma Brilliant dan meminta izin untuk melaksanakan pengabdian

c. Menjelaskan setiap jobdesk untuk seluruh panitia pengabdian

d. Mempersiapkan bahan bahan dan kebutuhan yang diperlukan selama kegiatan pengabdian

Panitia pengabdian melakukan koordinasi dengan team serta melakukan pembahasan untuk persiapan yang meliputi :

a. Materi dasar tentang konsep bahasa inggris

b. Penjelasan tentang video atau film bahasa inggris

c. Penjelasan praktek langsung tentang speaking dan listening menggunakan bahasa inggris

\section{Pelaksanaan}

Pelaksanaan kegiatan pelatihan berbasis ICT ini menggunakan media video. Metode pelaksanaannya yanitu dengan memebrikan materi terlebih dahulu, kemudian dilanjutkan dnegan praktek bersama dan diakhiri dengan sedikit games untuk meningkatkan antusias minat siswa.

Tabel 1. Uraian Pekerjaan pengabdian

\begin{tabular}{|l|l|l|}
\hline No & \multicolumn{1}{|c|}{$\begin{array}{c}\text { Uraian } \\
\text { Pekerjaan }\end{array}$} & \multicolumn{1}{c|}{ Program } \\
\hline 1. & $\begin{array}{l}\text { Pembuatan materi } \\
\text { tentang konsep } \\
\text { bahasa inggris }\end{array}$ & $\begin{array}{l}\text { Pemaparan } \\
\text { tentang materi } \\
\text { bahasa inggris } \\
\text { mulai dari } \\
\text { struktur, simple } \\
\text { tense dan lainnya }\end{array}$ \\
\hline 2. & $\begin{array}{l}\text { Pencarian film } \\
\text { atau video } \\
\text { bersubtitle bahasa } \\
\text { inggris }\end{array}$ & $\begin{array}{l}\text { Pelatihan untuk } \\
\text { memahami } \\
\text { percakapan dan } \\
\text { mengartikan teks } \\
\text { bahasa inggris }\end{array}$ \\
\hline 3. & $\begin{array}{l}\text { Praktek langsung } \\
\text { berbicara antar } \\
\text { sesama peserta } \\
\text { dengan } \\
\text { menggunakan } \\
\text { bahasa inggris }\end{array}$ & $\begin{array}{l}\text { Praktek langsung } \\
\text { berbicara antar } \\
\text { sesama peserta } \\
\text { dengan } \\
\text { menggunakan } \\
\text { bahasa inggris }\end{array}$ \\
\hline
\end{tabular}

\section{HASIL DAN PEMBAHASAN}

Kegiatan pengabdian ini berlangsung pada hari Kamis 16 Januari 2020 di kelas 7 (halimatus sa'diyah) SMPIT Plus Bazma Brilliant yang beralamat di jalan sekolah komplek pertamina RU II Dumai. Kegiatan ini diikuti oleh 30 siswi kelas 7 (halimatus sa'diyah) dan kegiatan ini dibuka oleh wakasis SMPIT Plus Bazma Briliant yaitu Ibu Aini, S.Pd. Kegiatan ini diisi dengan pelatihan berbahasa inggris menggunakan simple tense. Pelatihan ini meliputi materi pengenalan dasar tentang struktur simple tense mulai dari bentuk positif, negatif dan introgratif. Selanjutnya dilanjutkan dengan pemutaran video percakapan berbahasa inggris dan kemudian siswa dituntut untuk praktek berbicara bahasa inggris dengan menggunakan simple present tense. kemudian siswa diberikan latihan dengan menjawab beberapa pertanyaan yang sudah disiapkan oleh tim pengabdian dan ditutup dengan games menyusun kalimat bahasa inggris dengan struktur simple present tense. 


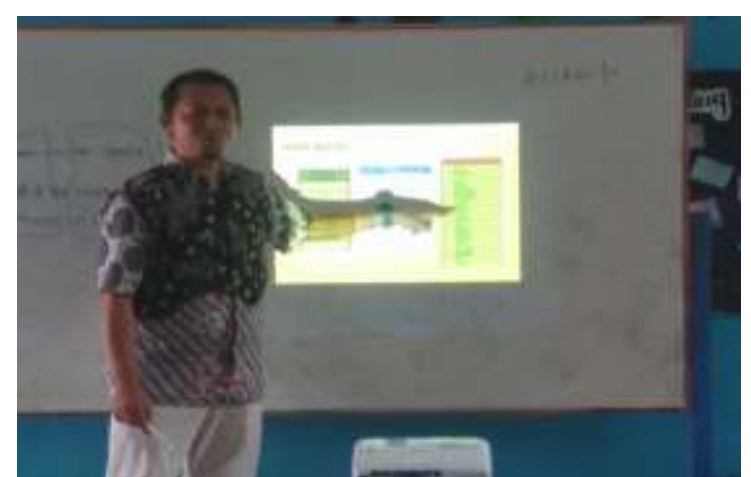

Gambar 1. Pemberian materi oleh Bp. Julanos

Materi pertama disampaikan oleh Bapak Julanos, M.Pd. yaitu pemberian materi tentang struktur simple present tense. Tim pengabdian menjelaskan materi tersebut mulai dari bentuk bentuk simple present tense dari bentuk positif, negatif dan kalimat introgratif. Materi selanjutnya adalah contoh kalimat simple present tense dan dilanjutkan dengan demo video percakapan bahasa inggris dengan menggunakan simple present tense. Siswa kemudian mempraktekan langsung untuk berbicara menggunakan bahasa inggris simplen present tense. Siswa sangat antusias sekali dalam praktek berbicara bahasa inggris karena mereka sangat semangat dalam menerima materi ini.

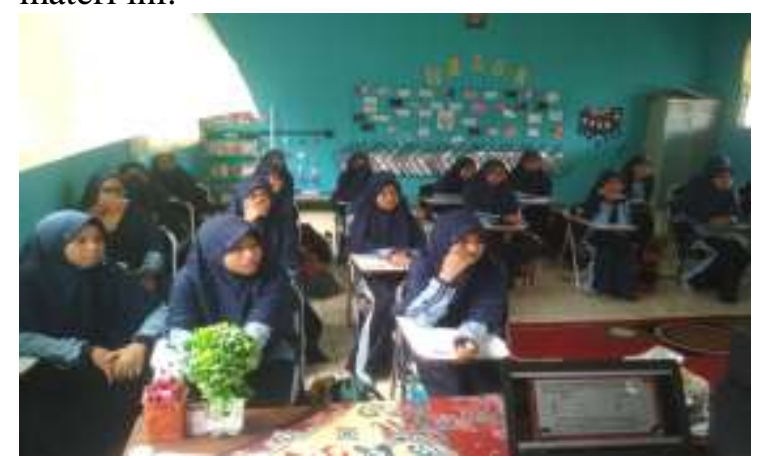

Gambar 2. Siswa antusias mendengarkan materi

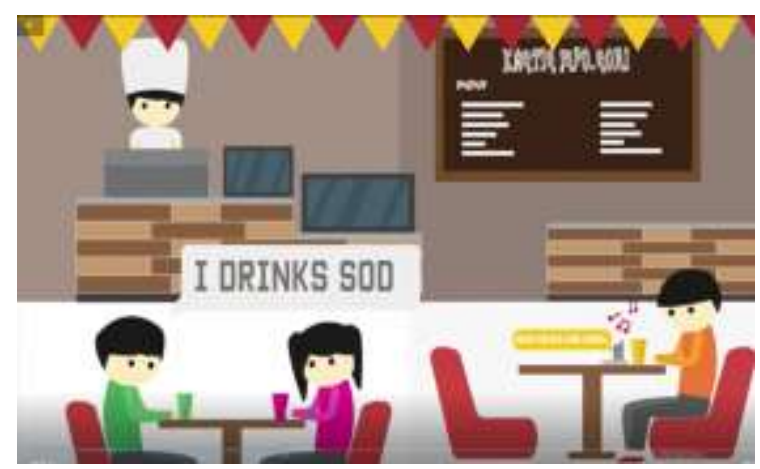

Gambar 3. Video animasi percakapan bahasa Inggris
Materi selanjutnya adalah para siswa diberikan beberapa latihan soal yang sudah disiapkan oleh tim pengabdian. Siswa sangat semangat mengerjakan dan berlomba lomba untuk menyelesaikan soal latihan dengan cepat dan tepat.

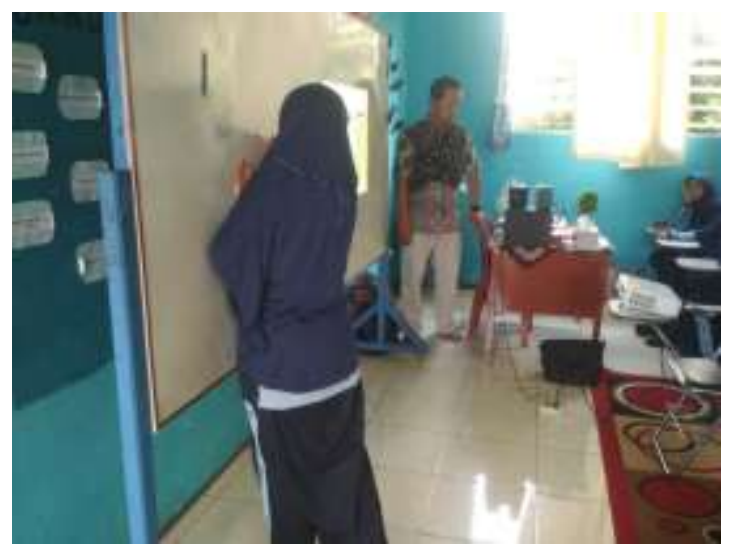

Gambar 4. Siswa praktek langsung kedepan

Materi terakhir diisi dengan games menarik yang sudah disiapkan sebelumnya. Gamesnya berupa menyusun sebuah kalimat dengan kata yang sudah diacak dan siswa dibuat berkelompok dengan jumlah anggota sebanyak 5 orang. Siswa diberikan waktu 5 menit untuk menyusun 5 buah kalimat yang sudah diacak katanya.

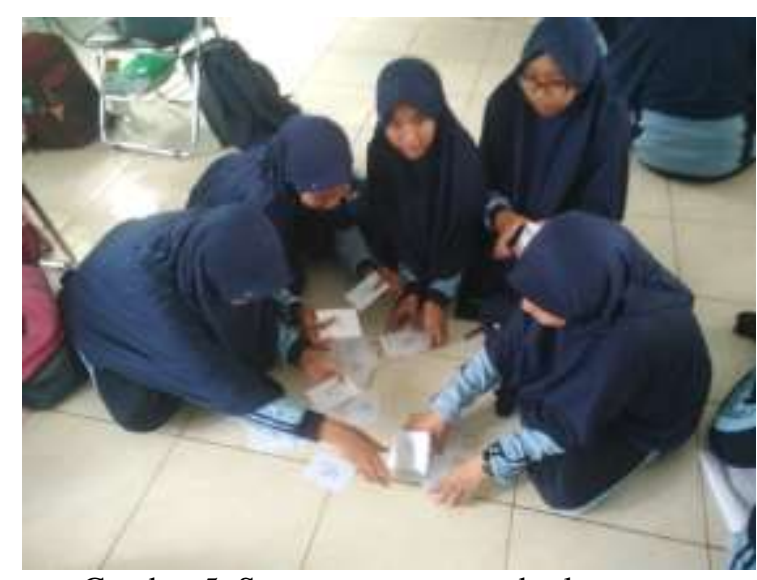

Gambar 5. Suasana saat games berlangsung

Pada games ini seluruh siswa sangat menikmati permainannya dengan dibuktikan mereka sangat senang dan berlomba lomba antar tim untuk menyelesaikan games tersebut. Karena dalam games tersebut terdapat doorprise yang menarik untuk siswa yang bisa menyelesaikan games dengan cepat dan tepat 


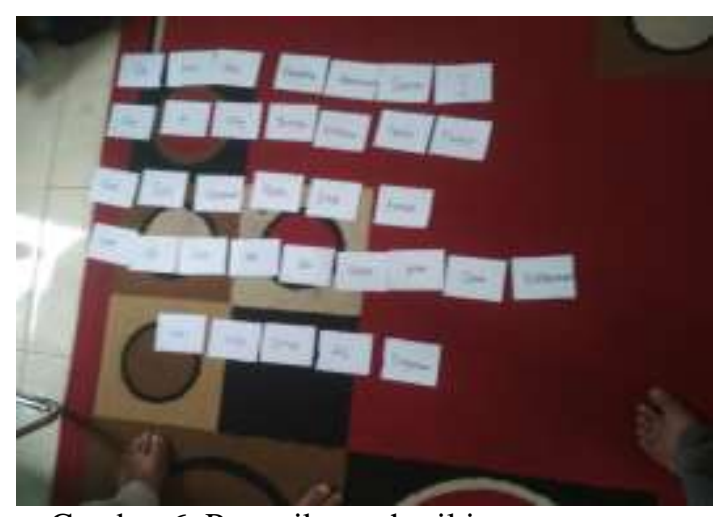

Gambar 6. Pemeriksaan hasil jawanan games

Saat paling mendebarkan dalam games tersebut adalah pada waktu pemeriksaan ketepatan jawaban. Masing masing kelompok berharap menjadi juaranya karena meerka berharap mendapat doorprise yang menarik yang sudah disiapkan tim pengabdian.
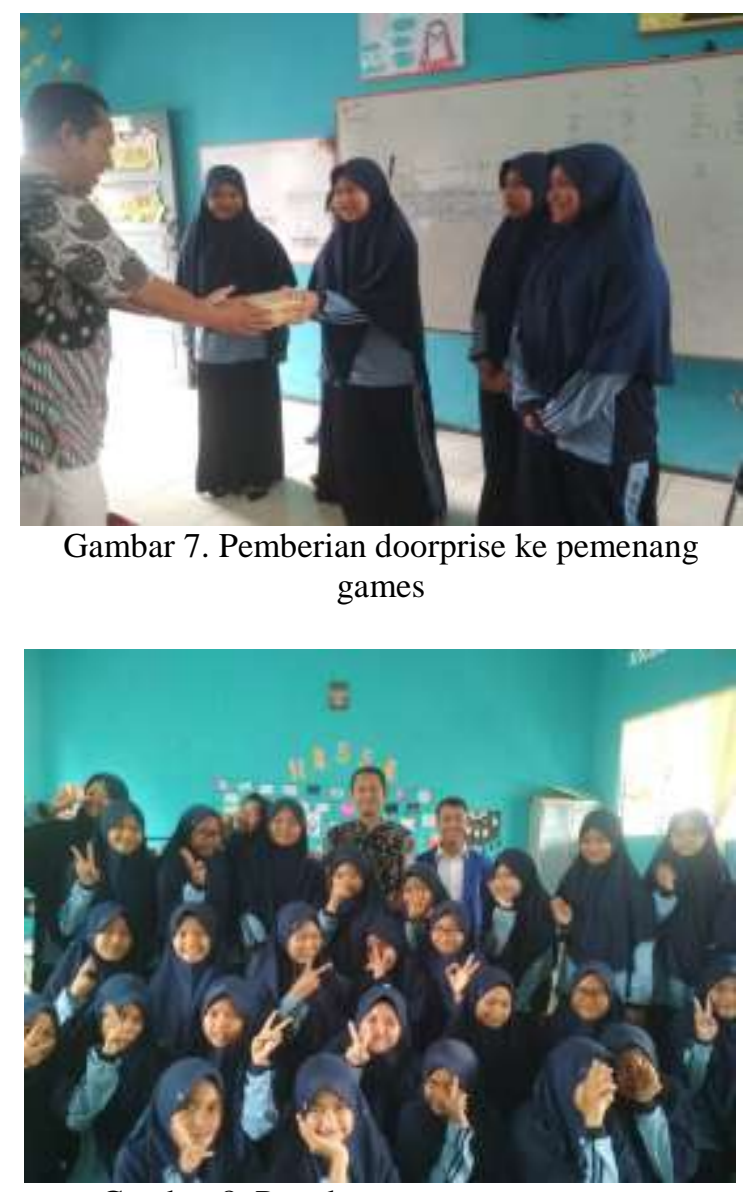

Gambar 8. Poto bersama saat penutupan

\section{KESIMPULAN}

Setelah kegiatan pengabdian ini dilaksanakan dapat diambil beberapa kesimpulan diantaranya siswa SMPIT Plus Bazma Brilliant sangat antusias dalam mengikuti seluruh kegiatan pengabdian ini. Hal ini dibuktikan dengan banyaknya siswa yang aktif selama kegiatan ini berlangsung. Selain itu siswa sangat bersemangat dan berlomba lomba ketika games berlangsung dan masing masing team berharap menjadi pemenang. Siswa banyak mendapatkan pengetahuan baru tentang pembelajaran bahasa inggris mulai dari kosa kata, menyusun kalimat berbahasa inggris serta percakapan berbahasa inggris.

\section{UCAPAN TERIMA KASIH}

Penulis mengucapkan terima kasih kepada LPPM Sekolah Tinggi Teknologi Dumai dan Seluruh pihak Sekolah SMP IT Plus Bazma Brilliant yang telah memberikan ijin dan membantu seluruh kegiatan demi suksesnya dalam kelancaran kegiatan pengabdian ini.

\section{DAFTAR PUSTAKA}

Andy, A., Rusfandi, R., \& Muzammil, L. (2018). Pelatihan Berbahasa Inggris Dengan Drilling Dan Repetition Bagi Karang Taruna Desa Jedong. Martabe: Jurnal Pengabdian Kepada Masyarakat, 1(2), 42. https://doi.org/10.31604/jpm.v1i2.42-48

Di, P., Operasi, D., \& Pusri, P. T. (2016). Pengaruh Motivasi Kerja Terhadap Kinerja Karyawan Level Pelaksana Di Divisi Operasi Pt. Pusri Palembang. Psikis: Jurnal Psikologi Islami, 1(2), 4353.

Emda, A. (2018). Kedudukan Motivasi Belajar Siswa Dalam Pembelajaran. Lantanida Journal, $\quad 5(2), \quad 172$. https://doi.org/10.22373/lj.v5i2.2838

Jelantik Swasta, I. B. (2014). Peran Pendidikan, Pelatihan Bahasa Inggris, Dan Teknik Kepemanduan Dalam Pengembangan Mina Wisata. Jurnal Cakrawala Pendidikan, 3(3), 474-482. https://doi.org/10.21831/cp.v3i3.2391

Muhammad, M. (2017). Pengaruh Motivasi Dalam Pembelajaran. Lantanida Journal, 4(2), 87. https://doi.org/10.22373/lj.v4i2.1881

Purnaningsih, P. (2017). Strategi Pemanfaatan Media Audio Visual untuk Peningkatan Hasil Belajar Bahasa Inggris. Jurnal Informatika Universitas Pamulang, 2(1), 34.

https://doi.org/10.32493/informatika.v2i1 .1503 
Ratminingsih, N. M. (2016). Efektivitas Media Audio Pembelajaran Bahasa Inggris Berbasis Lagu Kreasi Di Kelas Lima Sekolah Dasar. JPI (Jurnal Pendidikan Indonesia), $\quad 5(1), \quad 27$. https://doi.org/10.23887/jpiundiksha.v5i1.8292

Santosa, R. B. (2018). Motivasi Dalam Pembelajaran Bahasa Inggris: Studi Kasus Pada Mahasiswa Jurusan Pendidikan Bahasa Inggris IAIN Surakarta. Jurnal Ilmiah Didaktika,

18(1), 87. https://doi.org/10.22373/jid.v18i1.3089

Sulasih, S. (2017). Pembelajaran Bahasa Inggris Melalui Multimedia. Jurnal Informatika Universitas Pamulang, 2(4), 200.

https://doi.org/10.32493/informatika.v2i4 .1441

Tadulako, U. (2018). Peningkatan Kualitas Pembelajaran Bahasa Inggris Melalui, 1(2), 79-89. 